Hydraulic Engineering Repository

Ein Service der Bundesanstalt für Wasserbau

Ettema, Robert; Nakato, Tatsuaki

\title{
Geotechnical Limit to Scour at Spill-through Abutments
}

Verfügbar unter / Available at:

https://hdl.handle.net/20.500.11970/100209

Vorgeschlagene Zitierweise / Suggested citation:

Ettema, Robert; Nakato, Tatsuaki (2010): Geotechnical Limit to Scour at Spill-through Abutments. In: Burns, Susan E.; Bhatia, Shobha K.; Avila, Catherine M. C.; Hunt, Beatrice E. (Hg.): Proceedings 5th International Conference on Scour and Erosion (ICSE-5), November 7-10, 2010, San Francisco, USA. Reston, Va.: American Society of Civil Engineers. S. 125-131. 


\title{
Geotechnical Limit to Scour at Spill-through Abutments
}

\author{
R. Ettema', M. ASCE and T. Nakato², L.M. ASCE
}

'College of Engineering and Applied Science, the University of Wyoming, Laramie, WY 82071, PH: (307) 766-6458; e-mail: rettemalouwyo.edu

2Consulting Engineer, 618 Pine Ridge Road, Coralville, IA 52241; PH: (319) 351-

2504; e-mail: mollusk007@gmail.com

\begin{abstract}
For spill-through bridge abutments adjoining waterways, practically all field cases of failure attributable to scour show a geotechnical failure of the spill slope of earthfill embankment associated with the abutment. The extent of scour and the maximum scour depth attainable at an abutment indeed are limited by the geotechnical stability of the earthfill embankment at the abutment. For a given design flow, the stability of the embankment limits scour depth. The actual region of scour leading to embankment failure is itself unremarkable. Typically, scour depths at spill-through abutments are modest, at least when viewed after the flood event producing the scour, and when other factors such as channel morphology effects are excluded. Though numerous illustrations of scour at spill-through abutments show failed embankment and channel bank, methods currently available for estimating scour do not address the geotechnical aspects of scour at spill-through abutments. This paper presents a method for relating scour depth to the strength properties of an abutment's compacted earthfill embankment.
\end{abstract}

\section{INTRODUCTION}

This paper discusses important geotechnical aspects of spill-through abutment scour (Figure 1a), and shows that as scour deepens it reduces the stability of the abutment's earthfill spill-slope. When the slope is exceeded, spill-slope material slides into the scour region and the flow transports it away. Further deepening leads to more slope instability and erosion, until eventually, the erosion extends to the abutment column (Figure 1b). Still further erosion breaches the embankment, increasing the flow area, and relaxing flow velocities through the bridge waterway. In overall terms, scour at spill-through abutments can be characterized as being largely a geomechanics design concern, and less of a hydraulics concern. The paper outlines an approach to formulating the geotechnical limit to maximum scour depth at a spill-through abutment. The current investigation was conducted using a laboratory flume for three distinct scour conditions developed during the NCHRP 24-20 program (Ettema, et al. 2010).

\section{LABORATORY INVESTIGATIONS}

The laboratory experiments were conducted using a model channel fitted in a sediment re-circulating flume, $21.3-\mathrm{m}$ long, $4.0-\mathrm{m}$ wide, and $1.0-\mathrm{m}$ deep. The flume accommodated the half width of a compound channel; i.e., the flume width $=0.5 B$, where $B$ is the entire width of the compound channel. The width of the floodplain was adjustable, and the floodplain surface could be erodible or fixed. The main 
channel had a bed of uniform medium sand. The variable erodible natures of floodplain and embankment at bridge sites were simulated by means of tests with the model channel configured in the following arrangements that bracket the variable erodibility of floodplain and embankment:

1. Fixed floodplain and the embankment, both taken to be practically resistant to erosion, whereas the main-channel bed was erodible;

2. Erodible floodplain and main channel bed (the two being formed of the same noncohesive sediment and equally erodible), with the embankment being erodible but armored with riprap stone; and,

3. Erodible floodplain and main-channel bed, with the embankment unarmored. The abutment was formed of the same noncohesive sediment as the mainchannel bed.

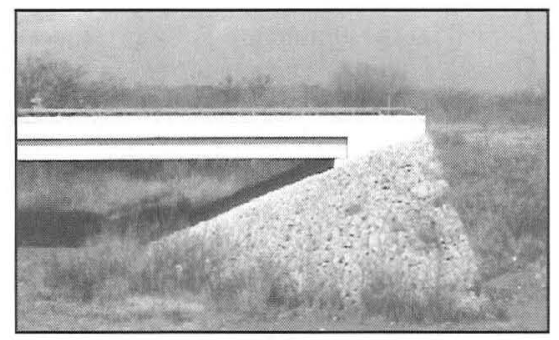

(a)

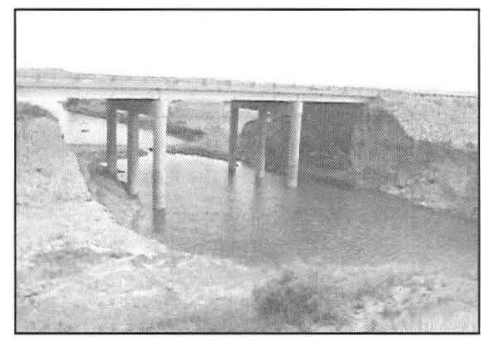

(b)

Figure 1. A spill-through abutment with earthfill approach embankment on a floodplain (a); and observation of Scour Condition A for a spill-through abutment on floodplain, depicting bank and embankment failures (b).

The following prototype considerations and dimensions were used in selecting the model layout, length scale, and dimensions for both types of abutments:

- A road width of $12.0 \mathrm{~m}$, in accordance with standard prototype two-lane roads. The road width includes $7.2 \mathrm{~m}$ plus $2.7 \mathrm{~m}$-wide shoulders, a total width of $12.6 \mathrm{~m}$;

- Pile spacing of $2 \mathrm{~m}$ to $3 \mathrm{~m}$;

- Pile diameter of $0.3 \mathrm{~m}$;

- The base of the pile cap submerged approximately $1.0 \mathrm{~m}$ below the original level of the floodplain bed;

- A 2-horizontal:1-vertical (2H:1V) constructed side slope of the earthfill embankment connected to the abutment; and,

- A 2H:1V slope of the bank between the floodplain and the main channel

Considerations of the flume's size led to selection of a geometrically undistorted length scale of 1:30 for the experiments. The model spill-through abutments were formed around a "standard-stub abutment," which consists of a 
concrete stub supported by a pile cap on two rows of circular pipes. The design and dimensions of standard-stub abutments commonly used by the Illinois, Iowa, and New York Departments of Transportation were used in the study.

\section{SCOUR CONDITIONS CONSIDERED}

Abutment scour may involve three distinct scour conditions (Ettema, et al. 2008; Ettema et al. 2010), herein termed Scour Conditions A, B, and C. These scour conditions were observed in the flume experiments and as well as at actual bridge sites:

- Scour Condition A occurs as scour of the main channel portion of a compound channel;

- Scour Condition B is scour of the floodplain, and occurs for abutments set well back from the main channel; and,

- Scour Condition $\mathrm{C}$ is a scour form that develops when breaching of an abutment's embankment fully exposes its abutment-column structure such that scour develops at the abutment column as if it were a pier.

For Scour Condition A, a useful analytical framework with which to relate maximum flow depth (incorporating maximum scour depth), $Y_{M A X}$, to flow conditions and boundary sediment or soil is to plot the dimensionless parameters $Y_{M A X} / Y_{C}$ and $q_{2} / q_{1}$. Here, $Y_{C}$ is the flow depth estimated for live-bed flow through a long contraction; $q_{2}$ is the area-average unit discharge of flow through the bridge section; and, $q_{1}$ is the area-average unit discharge of flow through the main channel upstream of the bridge site. At lower values of $q_{2} / q_{1}$, scour depth (and $Y_{M A X} / Y_{C}$ ) is governed by the local flow field around an abutment. However, for large values of $q_{2} / q_{1}$, scour development is governed by flow contraction, so that $Y_{M A X} / Y_{C}$ asymptotically approaches about 1.1. The approximate 10 percent increase is attributable to local concentration of flow and turbulence generated by flow around the abutment.

For Scour Condition B, a useful analytical framework with which to relate maximum flow depth (incorporating maximum scour depth), $Y_{M A X}$, to flow conditions and boundary sediment or soil is to plot the dimensionless parameters $Y_{M A X} / Y_{C}$ and $q_{f 2} / q_{f}$. Here, $Y_{C}$ is the flow depth estimated for clear-water flow through a long contraction; $q_{f 2}$ is the area-average unit discharge of flow through the floodplain portion of the bridge section; and, $q_{f}$ is the area-average unit discharge of flow over the floodplain upstream of the bridge site. The trend for $Y_{M A X} / Y_{C}$ versus $q_{f z} / q_{f}$ is essentially the same for $Y_{M A X} / Y_{C}$ and $q_{2} / q_{1}$.

For Scour Condition $\mathrm{C}$, scour depths must be estimated in a semi-empirical manner similar to that used for estimating scour depth at a pier of complex geometry. Scour is governed by the highly three-dimensional flow field developed at an exposed pier-like column.

\section{GEOTECHNICAL LIMIT TO MAXIMUM SCOUR DEPTH}

The maximum scour depth attainable at an abutment is limited by the geotechnical stability of the earthfill embankment at the abutment. For a given design flow, scour cannot deepen below this limit. Figure 2 illustrates this limit in simple 
terms for an embankment set back on a floodplain. As scour deepens, it reduces the stability of the earthfill embankment at the abutment, adjusting the embankment slope to its equilibrium slope. When the slope is exceeded, embankment material slides into the scour region (Figure $2 \mathrm{a}$ ) and the flow transports it away. Further deepening leads to more slope instability and erosion, until eventually, the erosion extends to the abutment column. Because the cross section of flow increases (Figure 2b), additional erosion results in breaching of the embankment and relaxation of the flow around the abutment.

It is possible to formulate the geotechnical limit to maximum scour depth. Figure 2 illustrates this limit. As indicated in Figure 2a, and found in the flume experiments, the location of deepest scour, $d_{S \max }$, was a radial distance, $R$, out from the abutment column. For the present study (and many abutment embankments), the constructed embankment slope was 2 horizontal to 1 vertical, such that the requirement for embankment slope stability, when the slope extends back to the abutment column, is

$$
\theta_{S}=\tan ^{-1}\left(\frac{E_{H}+d_{S \max }}{R}\right)
$$

where $E_{H}$ is embankment height. Adjusting Eq (1), gives an estimate for the limiting values of $d_{\text {Smax }}$;

$$
d_{\text {Smax }}=R \tan \theta_{S}-E_{H}
$$

The flume experiments showed that $R$ varied with the abutment length parameter $L / B_{f}$ (or essentially $q_{2} / q_{1}$ ), as indicated in Figure 3, which includes data from similar measurements reported by Barkdoll et al. (2007) who studied the use of riprap aprons as an abutment-scour counter-measure. The two data sets are in reasonably good agreement. Barkdoll et al. (2007) suggest for $R$,

$$
\frac{R}{Y_{f}}=4\left(\frac{L}{Y_{f}}\right)^{0.2}
$$

Consequently, the limiting scour depth can be estimated as

$$
d_{S \max }=4\left(\frac{L}{Y_{f}}\right)^{0.2} Y_{f} \tan \theta_{S}-E_{H}
$$

In other words, the maximum scour depth at the abutment should not exceed the limit given by Eq (4). Note that this limit can actually be attained, especially when $\theta_{S}$ is large, such as for an earthfill embankment formed of a compacted stiff clay. A larger scour depth leads to breaching of the embankment and flow relaxation through the bridge waterway (Figure $2 b$ ). The limiting scour-depth analysis should be further investigated for a range of earthfill materials, along with varying combinations of compacted embankment earthfill and floodplain soils. The present study was limited largely to uniform noncohesive sediment. The foregoing formulation of Eqs (1) through (4) is somewhat simplified, but is nonetheless indicative of how to estimate a limiting scour depth. 


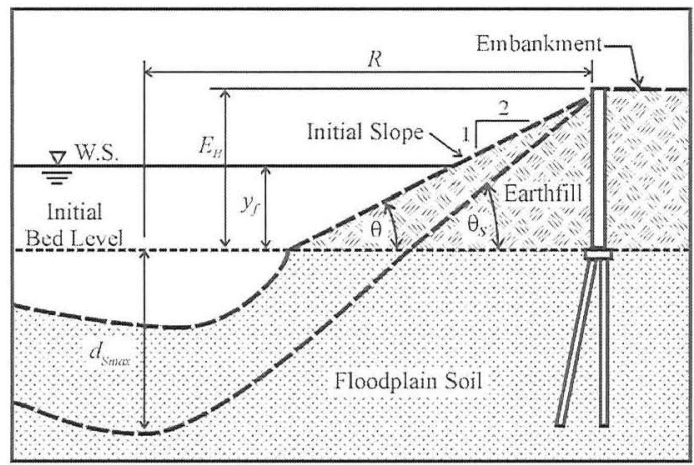

(a)

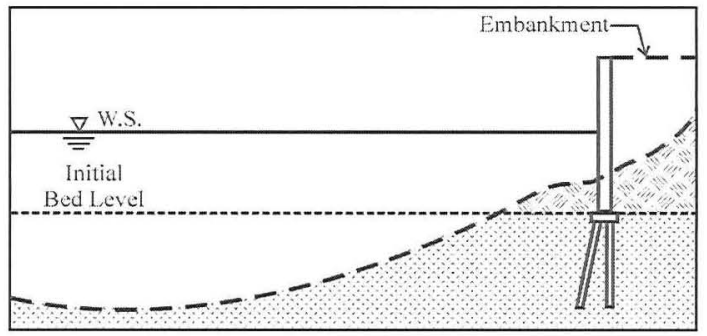

(b)

Figure 2. Deepening scour destabilizes the embankment face, causing the slope to fail geotechnically, and to erode back to a limiting condition. When the slope erodes back past the abutment column, the embankment breaches, and Scour

Condition $B$ attains an equilibrium state: the scour limit for an embankment face eroded back to an extent defined in terms of angle for embankment-slope stability, $\theta_{S}$, and column position (a); and, embankment failure beyond this limit induces leads to embankment breaching and flow relaxation (b).

It could be noted for an analysis of abutment geotechnical stability that riprap presence does not enhance geotechnical stability. Riprap adds weight to the slope, but does not increase the shear strength of the earthfill forming the embankment.

For abutments on footing foundations, a limiting maximum scour-depth coincides with the undermining of the footing and the possible geotechnical collapse of the earthfill embankment behind the abutment column. This limit also could be formulated, at least in approximate terms. A formulation is not given here, but the photo shown subsequently in Figure 4 for a vertical abutment illustrates such a geotechnical collapse, and directly indicates how the formulation might be formulated. 


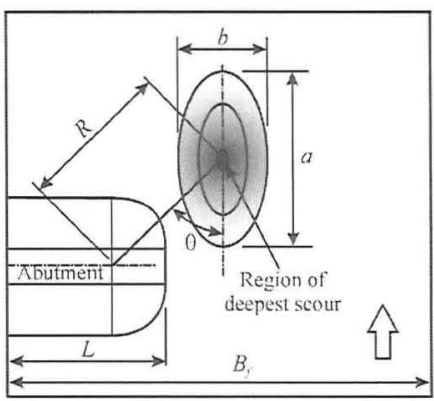

(a)

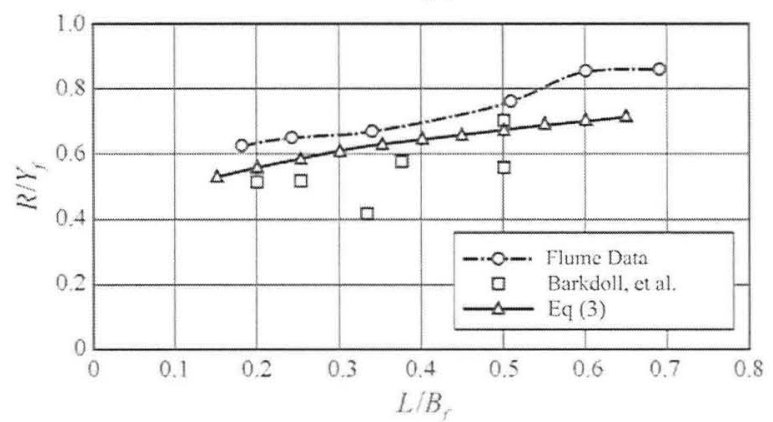

(b)

Figure 3. Definition sketch for distance, $R$, to deepest scour (a), and variation of $R / Y_{f}$ versus $L / B_{f}(\mathrm{~b})$.

\section{CONCLUSIONS}

The new design approach replaces the old notion of treating abutment scour as a hydraulic erosion problem with the arguably more accurate notion that abutment scour essentially is a geotechnical problem. Most abutment failures are geotechnical failures, which limit the depth to which scour can develop. This paper offers a simple formulation for estimating scour-depth based on the geotechnical stability of the abutment spill-slope. Additionally, this paper presents photos of abutment scour illustrating the geotechnical failure of abutments. The limiting scour depth at bridge abutment for spill-through abutments is given by Eq (4).

Moreover, the study shows that limiting scour depth does not depend on arbitrary assumptions about combining bridge-waterway contraction scour and local scour at the abutment structure, a notion that the study's flume experiments do not support. Rather, the study shows that abutment scour is essentially scour at a short contraction, for which the combined influences of non-uniform distribution of flow passing around an abutment, and the generation of large-scale turbulence in flow, passing around an abutment are intrinsically linked. 


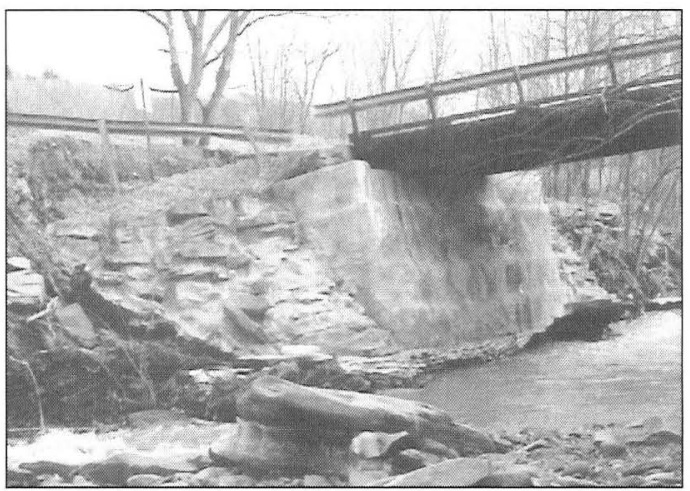

Figure 4. This photo illustrates the importance of embankment strength with respect to the development of abutment scour: the slope failure of the embankment immediately behind a wing-wall abutment founded on a spread footing.

\section{ACKNOWLEDGMENT}

The investigation reported herein was conducted for National Cooperative Highway Research Program (NCHRP) under Project 24-20.

\section{REFERENCES}

Barkdoll, B., Ettema, R., and Melville, B. (2007). "Countermeasures to protect bridge abutments from scour." Report 587, National Cooperative Highway Research Program, NCHRP 24-18, Transportation Research Board, Washington, D.C.

Ettema, R., Nakato, T., Yorozuya, A., and Muste, M. (2008). "Three abutment scour conditions investigated with laboratory flumes," Proc. of the 4th International Conference on Scour and Erosion (ICSE-4), Paper No. A-18, Tokyo, Japan, November 5-7, pp. 208-213.

Ettema, R., Nakato, T., and Muste, M. (2010). "Estimation of scour depth at bridge abutments," Draft Final Report, National Cooperative Highway Research Program, NCHRP 24-20, January. 